\title{
Use of Biochemical Markers for the Assessment of Organic Pollutant Contamination of the Vltava river, Czech Republic
}

\author{
Marcela Havelková ${ }^{,}$, Iveta Slatinská ${ }^{1}$, Zuzana Široká ${ }^{1}$, Jana Blahová ${ }^{1}$, Jan Krijt², \\ Tomáš Randák ${ }^{3}$, Vladimír Žlábek ${ }^{3}$, Danka Haruštiaková ${ }^{4}$, Jiří Jarkovský4, \\ Zdeňka Svobodová ${ }^{1,3}$ \\ ${ }^{1}$ Department of Veterinary Public Health and Toxicology, Faculty of Veterinary Hygiene and Ecology, \\ University of Veterinary and Pharmaceutical Sciences Brno, Czech Republic \\ ${ }^{2}$ Institute of Pathological Physiology, First Faculty of Medicine, Charles University, Prague, Czech Republic \\ ${ }^{3}$ Research Institute of Fish Culture and Hydrobiology Vodňany, University of South Bohemia České \\ Budějovice, Vodňany, Czech Republic \\ ${ }^{4}$ Institute of Biostatistics and Analyses, Masaryk University, Brno, Czech Republic
}

Received November 11, 2008

Accepted February 9, 2009

\begin{abstract}
In this study, selected biochemical markers - cytochrome P450 (CYP 450), ethoxyresorufin$O$-deethylase (EROD), glutathione S-transferase (GST) and glutathione (GSH) - were measured in chub (Leuciscus cephalus L.) liver samples obtained from three locations on the Vltava river (Podolí, Podbaba and Vraňany) and from a control location nmicals commonly known as their inducers. These include polychlorinated biphenyls, hexachlorobenzene and octachlorostyrene measured in chub muscle and polyaromatic hydrocarbons measured in bear Vodňany. The levels of selected biomarkers should correlate with the concentration of cheottom sediments obtained from the same locations. The highest EROD activity (median $101.37 \mathrm{pmol} \cdot \mathrm{min}^{-1} \cdot \mathrm{mg}^{-1} \mathrm{protein}$ ), GST activity (median $42.82 \mathrm{nmol} \cdot \mathrm{min}^{-1} \cdot \mathrm{mg}^{-1}$ protein), and GSH concentration (median 8.01 $\mathrm{nmol} \cdot \mathrm{mg}^{-1}$ protein) were found in fish liver from the Podbaba location. There were no significant differences in CYP P450 level or EROD activity among the different locations. In Podbaba, GST activity $(P<0.01)$ and GSH concentrations $(P<0.001)$ were significantly higher than in the control location. The results of these analyses were correlated and a significant correlation was found between biochemical markers and their inducers. The results show that the use of biochemical markers in water quality assessment is a convenient method that can supplement classical chemical monitoring.
\end{abstract}

Cytochrome P450, EROD, GST, GSH, Leuciscus cephalus, river pollution

The Vltava river $(376.7 \mathrm{~km})$ is the longest river in the Czech Republic. The river passes through the capital, Prague, which is the largest metropolitan area in the country with approximately 1.2 million inhabitants. This conurbation is a major source of pollution for the adjacent aquatic environment. The Vltava river, as the major water collector of Prague, presents an ideal scenario to study the discharge of anthropogenic pollutants into the aquatic environment.

There have been many reports of chemical monitoring and aquatic environment pollution assessment carried out on the Vltava river (e.g., Stachel et al. 2003; Žlábek et al. 2005; Hajšlová et al. 2007). To evaluate the relevance of the results obtained by chemical monitoring, it is helpful to assess the effects of anthropogenic pollution on aquatic organisms by measuring specific indicators (biochemical markers). These biomarkers are measurable biochemical indicators, and their level or activity changes are in response to the exposure to substances with similar mechanisms of toxic action. The advantage of analyzing biomarkers lies in their ability to provide comprehensive information on the effects of pollution and also to reflect the synergistic and antagonistic effects of individual components contributing to pollution.

Address for correspondence:

MVDr. Marcela Havelková

Department of Veterinary Public Health and Toxicology

University of Veterinary and Pharmaceutical Sciences Brno

Palackého 1-3

61242 Brno, Czech Republic

Phone: +420 54156278027

E-mail: mhavelkova@vfu.cz

http://www.vfu.cz/acta-vet/actavet.htm 
In this study, elements of both phase I (cytochrome P450 and ethoxyresorufin- $O$ deethylase) and phase II (glutathione S-transferase and glutathione) of xenobiotic metabolism were used for the assessment of aquatic environment pollution in the Vltava river. These biomarkers were also used in previous studies conducted along the Vltava river (Široká et al. 2005; Randák et al. 2006; Havelková et al. 2007).

Cytochrome P450 (CYP 450) is an important biochemical marker of aquatic environment contamination. The most useful isoform of CYP 450 is the 1A subfamily used in water pollution monitoring. The strongest inducers of this isoform are polychlorinated biphenyls (PCB), polycyclic aromatic hydrocarbons $(\mathrm{PAH})$, nitrated polycyclic aromatic hydrocarbons (NPAH) and dioxins (e.g. 2,3,7,8-TCDD) that are commonly found in water (White et al. 1997; Nilsen et al. 1998; Schlenk and Di Giulio 2002). Induction of the CYP1A family happens via the aryl hydrocarbon receptor (AhR). Generally, the toxicity of a pollutant is related to the degree of its affinity to AhR. Following interaction with previously mentioned xenobiotic substances, $\mathrm{AhR}$ is carried to the nucleus, where it enhances gene expression in CYP1A and results in an increased synthesis of cytochrome proteins.

The presence of CYP1A is closely associated with the activity of enzyme ethoxyresorufin$O$-deethylase (EROD). Enzymatic activity of EROD is highly inducible and an extremely sensitive indicator for the presence of AhR agonists in the environment. Its activity is usually one of the first detectable and quantifiable responses of organisms to the presence of AhR agonists. The strongest and most important inducers of EROD activity seem to be polychlorinated dibenzo- $p$-dioxins (PCDDs) and dibenzofurans (PCDFs), polychlorinated biphenyls (especially non-ortho-substituted $\mathrm{PCBs}$ ), polycyclic aromatic hydrocarbons (PAHs) or pesticides (Whyte et al. 2000).

Glutathione and enzyme glutathione S-transferase (both of them involved in phase II of xenobiotic metabolism) were used as well for aquatic environment quality determination.

Intracellular tripeptide glutathione (L- $\gamma$-glutamyl-cysteinyl-glycine: $\mathrm{GSH}$ ) represents the most important molecule involved in the defense of cells against oxidative stress (Otto and Moon 1996; Mannervik and Danielson 1988). Catalyzed by an enzyme glutathione S-transferase (GST) conjugative reaction with GSH, this is the principal detoxication pathway for electrophilic xenobiotics. Glutathione S-transferase facilitates the nucleophilic attack of glutathione against an electrophilic part, thus transferring the substrate to the immediate vicinity of glutathione (Eaton and Bammler 1999). The result of this process usually forms a less reactive and more readily soluble product.

Glutathione S-transferase (GST) and GSH can also be used as biomarkers in fish, but their usefulness is less sustainable than in the case of CYP 1A (Van der Oost et al. 2003). The spectrum of potential GST inducers is variable. Increased overall GST activity has been demonstrated in the liver of various fish species after exposure to PCBs (PerezLopez et al. 2000; Perez-Lopez et al. 2002), PAHs (Noble et al. 1998; Henson et al. 2001), or pesticides (Frasco and Guilhermino 2002).

The aim of this study was to assess the environmental impact of Prague conurbation, a major source of aquatic pollution, on the Vltava river, using the biochemical markers in chub liver (Leuciscus cephalus L.). The results of these biochemical analyses were compared with the chemical analyses of chub muscle and bottom sediments for specific inductors of the measured biomarkers. Contamination levels of the selected localities were assessed on the basis of the results and the most polluted localities were revealed.

\section{Materials and Methods}

This study was conducted in accordance with national and institutional guidelines for the protection of human subjects and animal welfare (the law "Protection of Animals against Cruelty Act" No. 246/92 Collection of Law). 
Collection of fish samples

As the indicator-fish species, the chub (Leuciscus cephalus L.) was chosen because it represents an omnivorous species and was available at all sampling sites. From 10 to 12 males of chub were caught at each location from April to May 2005 by electrofishing and killed by severing the spinal cord after stunning. Biometric details of the fish are summarized in Table 1. The chubs were caught at three locations along the Vltava river and at the control site (a pond near Vodňany). The locations along the Vltava river were Podolí (upstream of Prague, $57 \mathrm{r}$. km), Podbaba (downstream of Prague, and downstream of the wastewater treatment plant, $40.3 \mathrm{r}$. km), and Vraňany (downstream of Prague, and a chemical factory in Kralupy nad Vltavou, $10 \mathrm{r}$. km). Fish from the ponds near Vodňany (South Bohemia, Czech Republic) were used as control group. Long-term monitoring of the quality of market-ready fish harvested in the Vodňany region has demonstrated only minimum concentrations of exogenous substances in fish from local ponds (Svobodová et al. 2003; Svobodová et al. 2004), thus making this location a suitable control site. The sampling sites are shown in Fig. 1.

Table 1. Biometric details of chub (Leuciscus cephalus L.) used in the study

\begin{tabular}{|l|c|c|c|}
\hline Location (Date of capture) & $\mathrm{n}$ & Mean weight \pm S.D. (g) & Age (min-max) (years) \\
\hline Vodňany pond (control locality) (4. 5. 2005) & 12 & $279 \pm 144$ & $3-6$ \\
\hline Podolí (upstream of Prague) (25.4.2005) & 10 & $331 \pm 96$ & $3-5$ \\
\hline Podbaba (downstream of Prague) (29.4.2005) & 10 & $290 \pm 146$ & $3-8$ \\
\hline Vraňany (downstream of Prague) (29.4.2005) & 12 & $718 \pm 296$ & $4-8$ \\
\hline
\end{tabular}

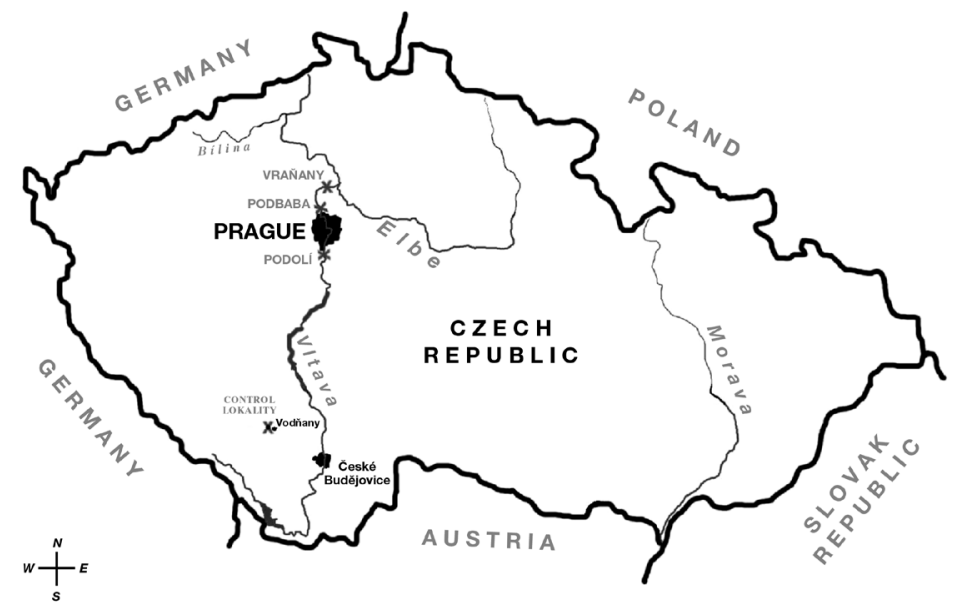

Fig. 1. Sample-collecting locations along the Vltava river and the control locality

\section{Collection of tissue samples}

Immediately after the fish were killed, individual liver samples (approximately $2 \mathrm{~g}$ ) were collected from each chub for the determination of its biomarkers. Samples were immediately frozen in liquid nitrogen and stored at $-80{ }^{\circ} \mathrm{C}$ until the enzyme assessments could be performed. Individual samples of fish muscle were collected for chemical analysis of the specific inductors of the mentioned biomarkers. Muscle samples were placed in thermo-boxes filled with dry ice, and stored at $-18{ }^{\circ} \mathrm{C}$ until they could be analyzed. The PAH levels in bottom sediment at all of the investigated locations were determined in sediment drawn near the river bank at a depth of $0.05-0.15 \mathrm{~m}$ by metal core samplers. After the particles larger than $0.5 \mathrm{~mm}$ were removed, the sediment samples were homogenized, refrigerated, and then transported $\left(4^{\circ} \mathrm{C}\right)$ to the laboratory, where they were stored at $-18{ }^{\circ} \mathrm{C}$ (Široká et al. 2005). The collection of bottom sediment samples was carried out according to the international norm ISO 5667-12, which provides guidance on the sampling of sediments from rivers, streams, lakes and similar standing waters and estuarines.

Determination of CYP 450 and EROD activity in liver samples

Before assessing the enzymes, microsomal protein concentrations were determined for each sample according to Lowry (1951). Depending on the protein concentrations, the required amounts of microsomal suspension were taken for the quantification of CYP 450 and the determination of EROD activity. 
Before the analysis, a thawed sample of liver tissue (from 0.5 to $2.0 \mathrm{~g}$ ) was placed into a homogenization buffer ( $\mathrm{pH}$ 7.4). The homogenized samples were centrifuged at $10000 \mathrm{~g}$ for $20 \mathrm{~min}$ at a temperature of $4{ }^{\circ} \mathrm{C}$. The supernatant was then carefully pipetted into ultracentrifugation tubes and re-centrifuged at $100000 \mathrm{~g}$ for 60 min at $4{ }^{\circ} \mathrm{C}$ (the ultracentrifuge Beckman OPTIMA - LE - $80 \mathrm{~K}$, USA). This second supernatant was removed and the microsomal fraction was washed with a homogenization buffer twice and then re-suspended in the buffer. This suspension was put into Eppendorf tubes and stored at $-80{ }^{\circ} \mathrm{C}$ until the enzymatic analysis could be performed. Visible light spectrophotometry $(390-490 \mathrm{~nm})$ was used to determine the total quantity of CYP 450. Measurements were made after cytochrome reduction by sodium dithionite, after the complex with carbon monoxide was formed. The suspension $(300 \mu \mathrm{l})$ was added into $6 \mathrm{ml}$ of phosphate buffer $(\mathrm{pH} 7.8)$. A small amount of dithionite was added and the solution was stirred and poured into two $3.5 \mathrm{ml}$ glass cells. The first of these was used as a standard measurement, and the second was bubbled with carbon monoxide for 20 s (Široká et al. 2005). Each sample was analyzed in triplicate and the mean value was used for statistical analysis. Measurements were made using the spectrophotometer UVIKON XS, Secomam, France.

The EROD catalytic activity was determined by fluorescence spectrophotometry (Perkin-Elmer Fluorescence Spectrophotometer 203, USA). The spectrophotometer monochromators were set at $535 \mathrm{~nm}$ and $585 \mathrm{~nm}$ for excitation and emission wavelength, respectively. In the presence of NADPH (nicotinamide adenine dinucleotide phosphate), EROD enzymatic activity converts the substrate ethoxyresorufin to resorufin, which is a fluorescent product. A phosphate buffer ( $\mathrm{pH} 7.8$ ), NADPH and microsomal suspension adequate for $0.2 \mathrm{mg} \cdot \mathrm{ml}^{-1} \mathrm{protein}$ were put into a cell. Ethoxyresorufin was added, and the increase in fluorescence was recorded for 5 min. EROD activity was subsequently calculated based on a comparison of fluorescence to the standard (resorufin) of known concentration. Each sample was analyzed in triplicate and the mean value was used for statistical analysis.

Determination of GSH and GST in liver samples

Before the analysis, frozen liver samples were extracted with a phosphate buffer. Four ml of the phosphate buffer ( $\mathrm{pH}$ 7.2) were added to the samples, which were homogenized and then centrifuged for $10 \mathrm{~min}$ at $2400 \mathrm{~g}$ and $4{ }^{\circ} \mathrm{C}$. The resulting supernatant was used for the determination of GST, GSH and protein concentration.

The catalytic activity of GST was measured spectrophotometrically by a modified method of Habig et al. (1974) using a biochemical analyzer Cobas Emira (Roche Diagnostics, Switzerland) at $340 \mathrm{~nm}$. The supernatant with a phosphate buffer ( $\mathrm{pH} 7.2), 0.02 \mathrm{M}$ CDNB (1-Cl-2,4-dinitrobenzene in methanol), and $0.1 \mathrm{M}$ reduced glutathione was pipetted into the cuvette of the biochemical analyzer. Specific activity was expressed as the nmol of the formed product, per minute per milligram of protein. Tripeptide glutathione was determined by E11man's method (1959) using the biochemical analyzer Cobas Emira. The amount of $50 \mu 1$ of $25 \%$ trichloroacetic acid was added into the $500 \mu \mathrm{l}$ of supernatant to precipitate the protein. This was vortexed for $5 \mathrm{~min}$ and, after $15 \mathrm{~min}$ of incubation at room temperature, it was centrifuged for $10 \mathrm{~min}$ at $2400 \mathrm{~g}$ at $4{ }^{\circ} \mathrm{C}$. The supernatant and reaction agents (buffer - 0.8 M Tris/HCl, 0.02 M EDTA pH 7.2 and 0.01 M 2,2-dinitro-5,5-dithiobenzoic acid in ethanol) were pipetted into sample cells. The absorbtion of coloured product was determined at $414 \mathrm{~nm}$ and concentrations (nmol $\cdot \mathrm{mg}^{-1}$ protein) were calculated according to a standard calibration. Protein concentrations were determined by a Bicinchoninic Acid Protein Essay Kit (Sigma-Aldrich) using bovine serum albumin as the standard (Smith et al. 1985). Each sample was analyzed in triplicate (for both GST and GSH) and the mean value was used for statistical analysis.

Determination of persistent organic pollutants in muscle samples

Polychlorinated biphenyl (PCB) congeners - IUPAC numbers 28, 52, 101, 118, 138, 153, 180, hexachlorobenzene (HCB), and octachlorostyrene (OCS) were determined in individual chub muscle samples using two-dimensional capillary gas chromatography. The isolation of target analytes from fish muscle was carried out by Soxhlet extraction into a hexanedichloromethane $(1: 1, \mathrm{v} / \mathrm{v})$ solvent mixture. Purification of the extracts was performed by Gel Permeation Chromatography on a Bio- Beads S-X3 column and mobile phase ethylacetate:cyclohexane (1:1, v/v) (Hajšlová et al. 1995). An HP 5890 Ser. II, gas chromatograph (Agilent Technologies, USA) was used for persistent organic pollutants assessment.

Determination of PAH in sediments

Before the assessments, sediment obtained from one location was mixed and a composite sample was prepared. These four sediment samples $\left(200 \mathrm{~g}\right.$ of sediment) were dried at $105^{\circ} \mathrm{C}$ for $16 \mathrm{~h}$ to a constant weight. Five grams of each sample were then mixed with anhydrous sodium sulphate and extracted with $50 \mathrm{ml}$ of a dichlormethane-methanol mixture. The combined extracts were evaporated on a rotary vacuum evaporator until dry, and the residue was dissolved in $4 \mathrm{ml}$ of chloroform. This crude extract was cleaned on the bio-Beads S-X3 column. Elution solvent was evaporated using a rotary vacuum evaporator until dry, and the residue was dissolved in $1 \mathrm{ml}$ of acetonitrile. Determination of PAHs in the purified sample was accomplished by reverse-phase HPLC with the column temperature at $35^{\circ} \mathrm{C}$ and the flow-rate of $1.2 \mathrm{ml} \cdot \mathrm{min}^{-1}$. Detection of analyte was carried out by programmable fluorescence detection (Hosnedl et al. 2003). The HPLC system used for the determination of target analytes was composed of the Hewlett-Packard 1050 pumping system, HP 1050 autosampler, and HP 1046 A fluorescence detector.

The PAHs assessed were fluorene, naphthalene, acenaphtyphene, phenanthrene, anthracene, fluoranthene, pyrene, benzo(a)anthracene, chrysene, benzo(b)fluoranthene, benzo(k)fluoranthene, benzo(a)pyrene, indeno $(1,2,3-\mathrm{c}, \mathrm{d})$ pyrene, benzo $(\mathrm{g}, \mathrm{h}, \mathrm{i})$ perylene, and dibenzo $(\mathrm{a}, \mathrm{h})$ anthracene. These 15 PAHs are European Union priority congeners (EPA 610). 
Statistical methods

Because normality of the distribution of the data obtained was not demonstrated, nonparametric techniques were used. The Kruskal-Wallis test was used to compare contaminant concentrations as well as the biochemical markers of contamination found at the individual locations. When the Kruskal-Wallis test showed significant differences between the locations $(P<0.05)$, multiple comparisons of all location pairs were subsequently performed. The Spearman's rank correlation coefficient was used to monitor the relationships between the selected biomarkers and organic pollutants within the various locations.

\section{Results}

Biochemical monitoring

The results of the phase I enzymes (CYP 450, EROD) in fish liver from four locations showed no significant differences between the investigated locations. Despite the fact that the highest level of CYP 450 (median $0.18 \mathrm{nmol} \cdot \mathrm{mg}^{-1}$ protein) was found in the Vraňany samples (downstream of Prague conurbation), and the lowest level (median $0.15 \mathrm{nmol} \cdot \mathrm{mg}^{-1}$ protein) was found in Podolí (upstream of the city), the differences in the levels assessed were very low. Increased EROD activity was found in chub liver from Podbaba (median $101.37 \mathrm{pmol} \cdot \mathrm{min}^{-1} \cdot \mathrm{mg}^{-1}$ protein) compared to the activity found in samples from Podolí (median $60.75 \mathrm{pmol} \cdot \mathrm{min}^{-1} \cdot \mathrm{mg}^{-1}$ protein). Just as in the recorded CYP 450 levels, EROD activity levels found in fish liver from the four locations were not significantly different among the sampling sites.

In fact, the results from phase II (enzyme GST and peptide GSH) seem to be more variable. The highest level of GST activity was found in chub liver from Podbaba (median $42.82 \mathrm{nmol} \cdot \mathrm{min}^{-1} \cdot \mathrm{mg}^{-1}$ protein), while the lowest activity was found at the control location, Vodňany (median $12.60 \mathrm{nmol} \cdot \mathrm{min}^{-1} \cdot \mathrm{mg}^{-1}$ protein), as expected. The activity of GST in samples from Podbaba was significantly higher $(P<0.01)$ than GST levels recorded at Vodňany, Podolí or Vraňany. As for the GSH concentration in chub liver, the results mimic those of GST activity. The highest GSH concentration was found in fish from Podbaba (median $8.01 \mathrm{nmol} \cdot \mathrm{mg}^{-1}$ protein), and the lowest concentration was found at the control locality Vodňany (median $0.97 \mathrm{nmol} \cdot \mathrm{min}^{-1} \cdot \mathrm{mg}^{-1}$ protein). Glutathione concentrations in livers from Podbaba and Vraňany were significantly higher $(P<0.001$ and $P<0.01$, respectively) than those from Vodňany. Glutathione concentrations in liver from Podbaba were significantly higher $(P<0.001)$ than GSH concentrations at Podolí.

The main characteristics of all the measured biomarkers in chub liver are summarized in Fig. 2.

\section{Chemical monitoring}

The results of chemical monitoring are summarized in Table 2 and Fig. 2. In all of the studied locations, concentrations of the selected chemical pollutants measured in chub muscle (PCB, HCB and OCS) were significantly higher $(P<0.01)$ than those in samples from the control location (Vodňany).

The location most contaminated by PCB was Vran̆any, where the median of PCB concentration found in chub muscle samples was $123.10 \mu \mathrm{g} \cdot \mathrm{kg}^{-1}$ muscle, wet weight (w. w.). The lowest PCB concentration was found at the control location Vodñany (median $8.15 \mu \mathrm{g} \cdot \mathrm{kg}^{-1}$ muscle, w. w.). The PCB concentrations in the muscle samples of chub from Podolí, Podbaba, and Vraňany were significantly higher $(P<0.001)$ than those from the control location Vodňany.

The results of HCB determination in chub muscle obtained from Podbaba and Vraňany have the same value (median $1.45 \mu \mathrm{g} \cdot \mathrm{kg}^{-1}$ muscle, w. w.), as these two locations present the most contaminated sites. The lowest amount of contamination was found at the control site at Vodňany (median $0.56 \mu \mathrm{g} \cdot \mathrm{kg}^{-1}$ muscle, w. w.). The HCB concentrations in chub muscle from Podbaba and Vraňany were significantly higher $(P<0.01)$ than those from Podolí, and from the control site. 

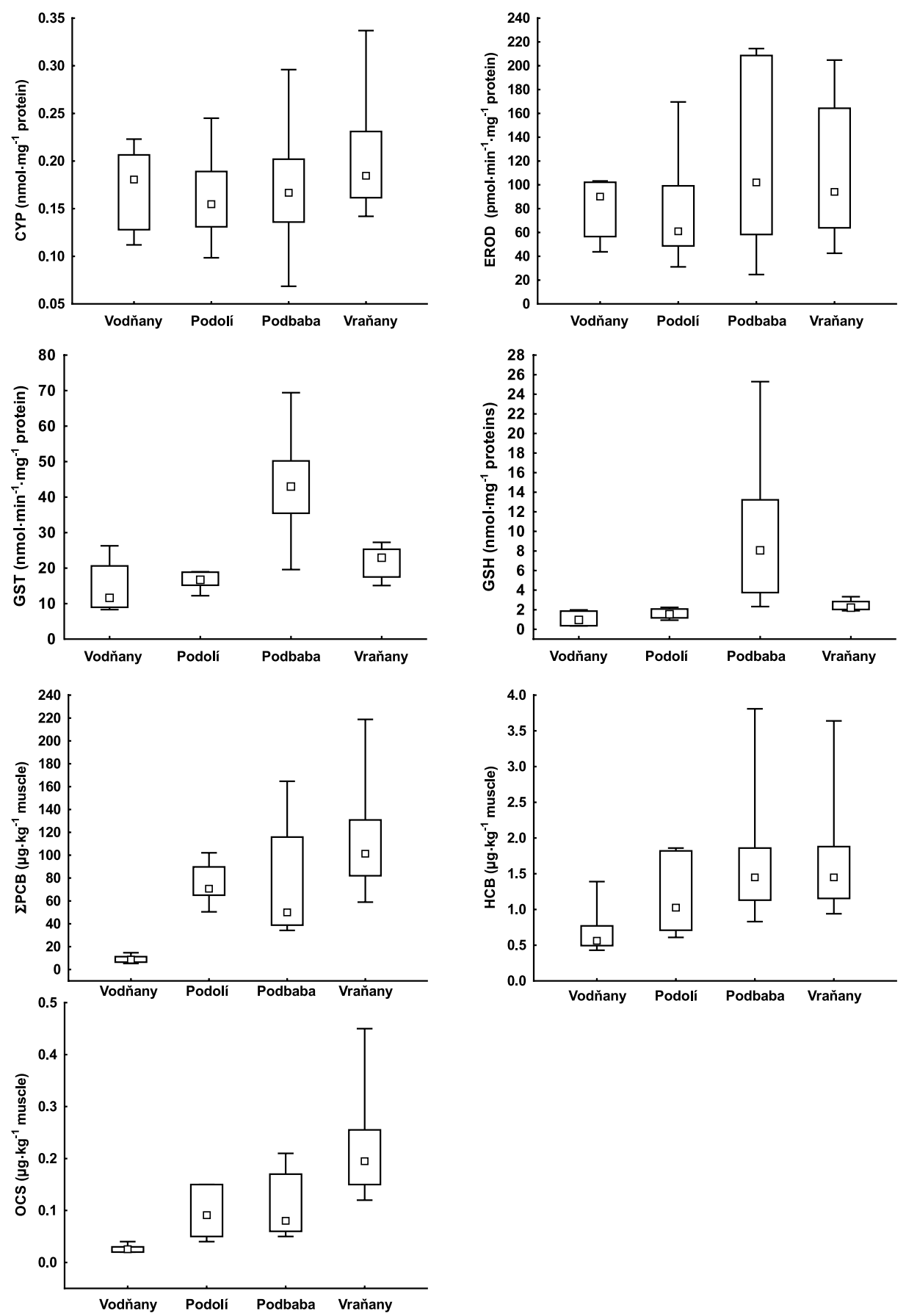

Fig. 2. Biochemical characteristics and POPs concentrations in muscle samples of chub from three locations along the Vltava river and from the control locality Vodňany 
Table 2. Content of 15 PAHs in bottom sediments

\begin{tabular}{|l|r|r|r|r|}
\hline PAH compounds* & \multicolumn{3}{|c|}{ Location } \\
\hline & Vodňany & Podolí & Podbaba & Vran̆any \\
\hline Fluorene & 7.3 & 163.9 & 192.9 & 41.6 \\
\hline Naphthalene & 4.4 & 59.6 & 64.0 & 12.3 \\
\hline Acenaphtyphene & 5.0 & 117.6 & 120.4 & 8.1 \\
\hline Phenanthrene & 221.9 & 62.7 & 1084.2 & 1460.5 \\
\hline Anthracene & 7.9 & 284.9 & 317.4 & 24.1 \\
\hline Fluoranthene & 146.6 & 1992.9 & 2329.5 & 423.8 \\
\hline Pyrene & 114.7 & 1521.2 & 1792.7 & 234.8 \\
\hline Benzo(a)anthracene & 64.6 & 984.8 & 1062.2 & 117.6 \\
\hline Chrysene & 59.3 & 810.2 & 963.4 & 169.8 \\
\hline Benzo(b)fluoranthene & 74.3 & 965.1 & 905.4 & 362.4 \\
\hline Benzo(k)fluoranthene & 37.5 & 440.4 & 506.1 & 145.0 \\
\hline Benzo(a)pyrene, & 68.6 & 1082.1 & 954.6 & 108.3 \\
\hline Indeno(1,2,3-c,d)pyrene & 71.4 & 767.5 & 795.7 & 137.5 \\
\hline Benzo(g,h,i)perylene & 59.6 & 483.1 & 643.8 & 122.2 \\
\hline Dibenzo(a,h)anthracene & 7.5 & 88.9 & 86.7 & 13.6 \\
\hline E PAH & 791 & 10846 & 12195 & 2143 \\
\hline
\end{tabular}

* PAHs are reported as $\mu \mathrm{g} \cdot \mathrm{kg}^{-1}$ dry matter of bottom sediment

Referring to OCS, the situation is very similar to that in PCB; the Vran̆any location was confirmed to be the most affected by octachlorostyrene. The levels of OCS in chub muscle samples from this location were $0.20 \mu \mathrm{g} \cdot \mathrm{kg}^{-1}$ muscle w. w. (median value), and the lowest OCS level was found at the control site Vodňany (median $0.03 \mu \mathrm{g} \cdot \mathrm{kg}^{-1}$ muscle), again. The OCS concentrations in chub muscle from Podolí, Podbaba $(P<0.05)$ and Vraňany $(P<$ $0.001)$ were significantly higher than those from the control location.

The concentrations of individual PAH congeners and the sum of all congeners' concentration in bottom sediments from all four locations are shown in the Table 2. The highest values of $\Sigma 15$ PAH were found at Podbaba (12 $195 \mu \mathrm{g} \cdot \mathrm{kg}^{-1}$ dry matter of bottom sediment) and Podolí (10 $846 \mu \mathrm{g} \cdot \mathrm{kg}^{-1}$ dry matter of bottom sediment). PAH concentrations in bottom sediment from Podolí, Podbaba, and Vraňany were significantly higher ( $P<0.001$ and $P<0.05$, respectively) than those from the control location. The most abundant congeners found at the assessed locations were fluoranthene and pyrene.

Correlations between biochemical and chemical monitoring

Spearman rank correlations between biochemical markers and chemical monitoring in the indicator fish are summarized in Table 3. Significant correlations $(P<0.05)$ were found between the levels of phase I enzymes - CYP 450 and EROD. Significant correlations $(P<0.05)$ were also found between GST and GSH in chub liver, and persistent organic pollutants in chub muscle samples (PCB, HCB, OCS). Correlations between biochemical markers and $\mathrm{PAH}$ in sediment could not be determined, as PAH were assessed only in composite samples, and according to statistics, such data (composite sample versus individual sample) can not be correlated.

\section{Discussion}

Enzymes of phase I of xenobiotic detoxification

The biochemical assessment of phase I enzymes (CYP 450 and EROD activity) revealed no significant differences between the four locations. Although certain substances (e.g. $\mathrm{PCB}, \mathrm{PAH}$, dioxins or pesticides) have been shown to induce isoform CYP1A and EROD 
Table 3. Spearman rank correlation between biochemical characteristics and organic pollutants concentrations in muscles. Significant correlations at level $\alpha=0.05$ are given in bold

\begin{tabular}{|l|c|c|c|c|c|c|c|}
\hline & CYP & EROD & GST & GSH & $\begin{array}{c}\text { PCB } \\
\text { (muscle) }\end{array}$ & $\begin{array}{c}\text { HCB } \\
\text { (muscle) }\end{array}$ & $\begin{array}{c}\text { OCS } \\
\text { (muscle) }\end{array}$ \\
\hline CYP & & $\mathbf{0 . 3 4 4}$ & 0.079 & 0.089 & 0.086 & 0.028 & 0.085 \\
\hline EROD & & & 0.191 & 0.253 & 0.168 & 0.129 & 0.209 \\
\hline GST & & & & $\mathbf{0 . 7 1 8}$ & 0.261 & $\mathbf{0 . 4 7 8}$ & $\mathbf{0 . 4 3 3}$ \\
\hline GSH & & & & & $\mathbf{0 . 3 9 0}$ & $\mathbf{0 . 4 1 1}$ & $\mathbf{0 . 4 8 1}$ \\
\hline PCB (muscle) & & & & & & $\mathbf{0 . 7 6 6}$ & $\mathbf{0 . 9 0 7}$ \\
\hline HCB (muscle) & & & & & & & $\mathbf{0 . 8 1 3}$ \\
\hline OCS (muscle) & & & & & & & \\
\hline
\end{tabular}

activity in fish in both the laboratory and natural conditions (extensive reviews written by Van der Oost et al. 2003 and Whyte et al. 2000), no significant correlation was found between the phase I biochemical markers and the results of chemical analyses in our study. One possible explanation for our non-correlative results could be the differences in the predicate values of various isoforms of CYP 450. Only the total content of CYP 450 was assessed in this study, not specifically the 1A isoform. The response of total CYP 450 content is less sensitive than that in the case of the selected isoenzymes (Bucheli and Font 1995). It was demonstrated that single xenobiotic compounds can act as inducers of specific isoenzymes, but can inhibit others. This may result in a considerable alteration of isoenzyme levels, whereas the amount of total CYP 450 is not always affected.

However, the results of this present study suggest that increased PCB and PAH concentrations do not always result in an increase of CYP 450 levels. Results similar to those found in our study were reported in chub by Široká et al. (2005). In a study of contamination in the Labe and Vltava rivers (Czech Republic), they failed to find any significant increases in the activity of CYP 450 or EROD even at demonstrably increased PCB and PAH concentrations. The contents of both measured biochemical markers and organic pollutants were comparable to our results. On the other hand, Randák et al. (2006) and Havelková et al. (2007) demonstrated a positive correlation between phase I liver enzymes and organic pollutants (PCB) in the muscle of fish from the Vltava river (localities situated upstream and downstream of Prague) in their field studies of chub. The localities situated downstream of Prague showed the highest levels of CYP 450 content and EROD activity. These studies also confirmed the negative impact of the city of Prague on the aquatic environment.

The explanation for CYP 450 levels not responding to contaminants in the aquatic environment might possibly be due to the high concentrations of PCB and PAH substances (Brammel et al. 2004) or the presence of specific CYP 450 inhibitors (e.g. $\mathrm{Cu}, \mathrm{Zn}, \mathrm{Pb}$, $\mathrm{Cd}, \mathrm{Cr}$ or Ni) in the environment (Forlin et al. 1986; Fent and Bucheli 1994; Risso-de Faverney et al. 2000; Bozcaarmutlu and Arinc 2004). This inhibitory activity appears to result from competition with iron heme porphyrin binding. Moreover, inhibitors may be selective for a particular CYP 450 isoenzyme. Occasionally, different compounds are able to act as selective inhibitors towards CYP 450 within the same subfamily (Lew is 2001). However, low or increased concentrations of selected organic pollutants (PAH, PCB, $\mathrm{TCDD} / \mathrm{F}$ ) can act as CYP1A inducers, whereas high concentrations of these pollutants can act as inhibitors of the CYP1A subfamily (Stegeman et al. 1997; Schlezinger and Stegeman 2001). Another factor that can influence the levels of measured biomarkers is the duration of exposure of water organisms to an efficient concentration of pollutants. The rapid rise of EROD activity after 1-3 days of exposure is typical for compounds that are easily metabolized (PAH) (Sleiderink and Boon 1996; Wolkers et al. 1996). On the other hand, in the case of halogenated inducers (e. g. PCDD/F or PCB), the induction of 
EROD activity or CYP 450 content lasts much longer (from 3 to 16 weeks) (Whyte et al. 2000). Finally, the effects of stress or defense mechanisms which allow the fish to survive in a highly contaminated environment should also be considered.

Enzymes of phase II of xenobiotic detoxification

The results of GST activity and GSH concentration indicate that the localities downstream of Prague are exposed to these quantities of pollutants inducing these markers, including well-known inducers such as PCB and PAH. Chub liver from Podbaba (downstream of Prague) showed approximately 3 times higher amount of GST activity and 10 times higher amount of GSH concentration than fish from the control site. Increased GST activity caused by the presence of PAH and PCB in the aquatic environment has been corroborated by many laboratory and field studies at different rivers involving various fish species (Henson et al. 2001; Perez-Lopez et al. 2002; Pandey et al. 2003; Ahmad et al. 2006). Similarly, increased concentrations of liver GSH compared with the control sites have been observed in English sole (Pleuronectes vetulus) collected from a PCB- and PAH-polluted section in Washington (Nishimoto et al. 1995) and in brown bullhead (Ameiurus nebulosus) from a PAH-polluted section in New York (Eufemia et al. 1997).

In contrast to a certain number of studies demonstrating increased GST activity in fish from various locations contaminated with organic pollutants (PAH, PCB, PCDD/PCDF), most studies did not show any significant differences between the fish from the control and polluted sites.

Regarding comparison of the sensitivity of phase I and phase II biomarkers, our results showed that phase II biomarkers were more sensitive in this case, which is extremely rare. These biomarkers tested on various fish species have usually proved to be less dependable as an indicator of environmental contamination (Van der Oost et al. 2003). A possible explanation for our differing results may be due to variations in the sensitivity of fish species to the effects of organic contaminants or to the presence of the phase I enzyme inhibitors and GST and GSH inducers at the monitored localities. Sen and Semiz (2007) found that ionic detergents strongly inhibit EROD activity, whereas much less inhibition was observed with GST catalyzed activities. Therefore, this inhibiting potential of detergents suggests that their contribution to the CYP1A induction has to be taken into account for a better interpretation of their environmental impact. The most abundant sources of ionic detergents are from households and sewage water from Prague.

\section{Chemical monitoring}

Increasing environmental pollution makes the bottom sediments a "sink" for hydrophobic chemicals, which can then be released back into the water. In this study, we focused on organic pollutants that are typically bio-accumulated in the environment and which can influence biomarkers.

The highest PAH concentrations (a total of 15 PAHs) in bottom sediments were found at Podbaba, which were consistent with the values of GST and GSH found in fish livers from this location. This site is situated downstream of Prague (and downstream of the wastewater treatment plant). The most abundant PAH congeners in bottom sediment samples were fluoranthene, phenanthrene and pyrene. Fluoranthene and pyrene are also the most abundant PAH congeners in the bottom sediment all over the world, e.g. in the Baltic Sea (Pikkarainen 2004), in Hong Kong (Ke et al. 2005) or in the Barents Sea, Russia (Savinov et al. 2003). Fluoranthene is found in many combustible products, along with other PAHs. Even if the highest concentration of fluoranthene in bottom sediment could be determined, this PAH congener seems to inhibit EROD activity, which was demonstrated in various studies on fish in vivo (Willett et al. 2001) or in vitro (Bols et al. 1999; Fent and Batscher 2000). Because of fluoranthene inhibition effect, CYP1A based bio-assessments may have underestimate the exposure of PAH mixtures. 
The highest concentrations of $\mathrm{PCB}, \mathrm{HCB}$ and $\mathrm{OCS}$ were detected at the localities situated downstream of Prague - Vraňany and Podbaba. All of these contaminants are of primary concern due to their persistence and bio-accumulation in the environment, and their toxicity to aquatic organisms. The use of PCBs was very wide (coolants and insulating fluids for transformers and capacitors; additives in PVC coatings for electrical wiring and electronic components; pesticide extenders, cutting oils, flame retardants, hydraulic fluids, adhesives, paints, and in carbonless copy paper). Hexachlorbenzene was used as a fungicide in agriculture, however, the main source of this chemical is presently the industry. Hexachlorbenzene is released into aquatic environment as a byproduct of chlorinated compounds (Bailey 2001). Octachlorostyrene is not commercially manufactured but has been reported to be an inadvertent byproduct of processes that combine carbon and chlorine at high temperatures. The probable source of these compounds could be both the Prague agglomeration and heavy industry near Vraňany (a chemical plant at Kralupy nad Vltavou).

Nevertheless, the highest levels from the majority of assessed biomarkers and chemical pollutants were found in Vraňany and Podbaba. Under normal conditions, levels of pollutants present in wastewaters succesively decrease according to the increased distance from the source of contamination. However, this was not the trend in our particular case; therefore, we must presume that pollution in the aquatic ecosystem downstream of Prague is disseminated over a large distance from the Prague agglomeration. Additionally, the negative impact on the aquatic environment could possibly stem from the chemical plant situated near Vraňany, and its influence on the environment deserves more investigation.

\section{Hodnocení kontaminace řeky Vltavy organickými polutanty prostřednictvím biochemických markerů}

Cílem práce bylo stanovit vybrané biochemické markery - cytochrom P450 (CYP 450), ethoxyresorufin-O-deethylasa (EROD), glutathion S-transferasa (GST) a glutathion (GSH) - v játrech jelce tlouště (Leuciscus cephalus L.). Jelci byli odloveni na třech lokalitách situovaných na řece Vltavě (lokality Podolí, Podbaba a Vraňany), jako kontrolní lokalita byla zvolena lokalita ve Vodňanech. Hodnoty stanovených biochemických markerů byly korelovány s výsledky chemického monitoringu, jenž byl zaměřený na stanovení významných induktorů těchto biomarkerů: polychlorované bifenyly, hexachlorcyklohexan a oktachlorstyren ve svalovině ryb a polyaromatické uhlovodíky v sedimentech dna. Nejvyšší hodnoty sledovaných biochemických markerů byly zjištěny v játrech ryb z lokality Podbaba (aktivita EROD: median $101.37 \mathrm{pmol} \cdot \mathrm{min}^{-1} \cdot \mathrm{mg}^{-1}$ proteinu, aktivita GST: median $42.82 \mathrm{nmol} \mathrm{min}{ }^{-1} \cdot \mathrm{mg}^{-1}$ proteinu a koncentrace GSH: median $8.01 \mathrm{nmol} \cdot \mathrm{mg}^{-1}$ proteinu). $\mathrm{V}$ prípadě cytochromu P450 a aktivity EROD nebyly zjištěny žádné významné rozdíly mezi sledovanými lokalitami. V př́ípadě aktivity GST a koncentrace GSH byly zjištěny významné rozdíly mezi lokalitou Podbaba a mezi kontrolní lokalitou Vodňany. Významná korelace byla zjištěna mezi výsledky chemického a biochemického monitoringu. Získané výsledky potvrdily, že využití biochemických markerů při hodnocení kontaminace vodního prostředí je vhodnou metodou, která doplňuje klasický chemický monitoring.

\section{Acknowledgements}

This research was supported by the Ministry of the Education, Youth and Sports of the Czech Republic (Project MSM 6215712402) and by the Ministry of Environment of the Czech Republic (Project SP/2e7/229/07).

\section{References}

Ahmad I, Pacheco M, Santos MA 2006: Anguilla anguilla L. oxidative stress biomarkers: An in situ study of freshwater wetland ecosystem (Pateira de Fermentelos, Portugal). Chemosphere 65: 952-962

Bailey RE 2001: Global hexachlorobenzene emissions. Chemosphere 43: 167-182 
Bols NC, Schirmer K, Joyce EM, Dixon DG, Greenberg BM, Whyte JJ 1999: Ability of polycyclic aromatic hydrocarbons to induce 7-ethoxyresorufin-Odeethylase activity in a trout liver cell line. Ecotox Environ Safe 44: $118-128$

Bozcaarmutlu A, Arinc E 2004: Inhibitory effects of divalent metal ions on liver microsomal 7-ethoxyresorufin$O$-deethylase (EROD) activity of leaping mullet. Mar Environ Res 58: 521-524

Brammell BF, Price DJ, Birge WJ, Elskus AA 2004: Apparent lack of CYP1A response to high PCB body burdens in fish from a chronically contaminated PCB site. Mar Environ Res 58: 251-255

Bucheli TD, Font K 1995: Induction of cytochrome-P450 as a biomarker for environmental contamination in aquatic ecosystems. Crit Rev Env Sci Tec 25: 201-268

Eaton DL, Bammler TK 1999: Concise review of the glutathione S-transferases and their significance to toxicology. Toxicol Sci 49: 156-164

Ellman GL 1959: Tissue sulfhydryl groups. Arch Biochem Biophys 82: 70-77

Eufemia NA, Collier TK, Stein JE, Watson DE, Digiulio RT 1997: Biochemical responses to sediment-associated contaminants in brown bullhead (Ameiurus nebulosus) from the Niagara River ecosystem. Ecotoxicology 6: 13-34

Fent K, Batscher R 2000: Cytochrome P4501A induction potencies of polycyclic aromatic hydrocarbons in a fish hepatoma cell line: Demonstration of additive interactions. Environ Toxicol Chem 19: 2047-2058

Fent K, Bucheli TD 1994: Inhibition of hepatic-microsomal monooxygenase system by organotins in-vitro in fresh-water fish. Aquat Toxicol 28: 107-126

Forlin L, Haux C, Karlsson-Norrgren L, Runn P, Larsson A 1986: Biotransformation enzyme-activities and histopathology in rainbow trout, Salmo gairdneri, treated with cadmium. Aquat Toxicol 8: 51-64

Frasco MF, Guilhermino L 2002: Effects of dimethoate and beta-naphthoflavone on selected biomarkers of Poecilia reticulata. Fish Physiol Biochem 26: 149-156

Habig WH, Pabst MJ, Jakoby WB 1974: Glutathione S-transferases. First enzymatic step in mercapturic acid formation. J Biol Chem 249: 7130-7139

Hajšlová J, Pulkrabová J, Poustka J, Čajka T, Randák T 2007: Brominated flame retardants and related chlorinated persistent organic pollutants in fish from river Elbe and its main tributary Vltava. Chemosphere 69: 1195-1203

Hajšlová J, Schoula R, Holadová K, Poustka J 1995: Analysis of PCBs in biotic matrices by 2-dimensional GCECD. Int J Environ An Ch 60: 163-173

Havelková M, Randák T, Žlábek V, Krijt J, Kroupová H, Pulkrabová J, Svobodová Z 2007: Biochemical markers for assessing aquatic contamination. Sensors 7: 2599-2611

Henson KL, Stauffer G, Gallagher EP 2001: Induction of glutathione S-transferase activity and protein expression in brown bullhead (Ameiurus nebulosus) liver by ethoxyquin. Toxicol Sci 62: 54-60

Hosnedl T, Hajšlová J, Kocourek V, Tomaniová M, Volka K 2003: 1-hydroxypyrene as a biomarker for fish exposure to polycyclic aromatic hydrocarbons. B Environ Contam Tox 71: 465-472

Ke L, Yu KSH, Wong YS, Tam NFY 2005: Spatial and vertical distribution of polycyclic aromatic hydrocarbons in mangrove sediments. Sci Total Environ 340: 177-187

Lewis DFV 2001: Guide to cytochromes P450 - Structure and function. In: Taylor \& Francis (Ed.): Substrate Selectivity and Metabolism. Taylor \& Francis Inc, London, pp. 86-89

Lowry OH, Rosebrough NJ, Farr AL, Randall RJ 1951: Protein measurement with folin phenol reagent. J Biol Chem 193: 265-275

Mannervik B, Danielson UH 1988: Glutathione transferases - structure and catalytic activity. Crit Rev Biochem 23: $283-337$

Nilsen BM, Berg K, Goksoyr A 1998: Induction of cytochrome P450 1A(CYP1A) in fish. In: Phillips \& Shephard (Ed.): Methods in molecular biology. Humana Press Inc., Totowa, NJ, pp. 423-438

Nishimoto M, Leeberhart BT, Sanborn HR, Krone C, Varanasi U, Stein JE 1995: Effects of a complex mixture of chemical contaminants on hepatic glutathione, L cysteine and gamma-glutamylcysteine synthetase in English sole (Pleuronectes vetulus). Environ Toxicol Chem 14: 461-469

Noble E, Barre H, Dierickx PJ 1998: Effect of diet and beta-naphthoflavone on hepatic and renal glutathione S-transferase isoenzymes in carp (Cyprinus carpio). Fish Physiol Biochem 18: 203-212

Otto DME, Moon TW 1996: Phase I and II enzymes and antioxidant responses in different tissues of brown bullheads from relatively polluted and non-polluted systems. Arch Environ Con Tox 31: 141-147

Pandey S, Parvez S, Sayeed I, Haque R, Bin-Hafeez B, Raisuddin S 2003: Biomarkers of oxidative stress: a comparative study of river Yamuna fish Wallago attu (Bl. \& Schn.). Sci Total Environ 309: 105-115

Perez-Lopez M, Anglade P, Bec-Ferte MP, Debrauwer L, Perdu E, Cravedi JP, Rouimi P 2000: Characterization of hepatic and extrahepatic glutathione S-transferases in rainbow trout (Oncorhynchus mykiss) and their induction by 3,3',4,4'- tetrachlorobiphenyl. Fish Physiol Biochem 22: 21-32

Perez-Lopez M, Novoa-Valinas MC, Melgar-Riol MJ 2002: Glutathione S-transferase cytosolic isoforms as biomarkers of polychlorinated biphenyl (Arochlor-1254) experimental contamination in rainbow trout. Toxicol Lett 136: 97-106

Pikkarainen AL 2004: Polycyclic aromatic hydrocarbons in Baltic Sea sediments. Polycycl Aromat Comp 24: 667-679 
Randák T, Žlábek V, Kolářová J, Svobodová Z, Hajšlová J, Široká Z, Janská M, Pulkrabová J, Čajka T, Jarkovský J 2006: Biomarkers detected in chub (Leuciscus cephalus L.) to evaluated contamination of the Elbe and Vltava rivers, Czech Republic. B Environ Contam Tox 76: 233-241

Risso-De Faverney C, Lafaurie M, Girard JP, Rahmani R 2000: Effects of heavy metals and 3-methylcholanthrene on expression and induction of CYP1A1 and metallothionein levels in trout (Oncorhynchus mykiss) hepatocyte cultures. Environ Toxicol Chem 19: 2239-2248

Savinov VM, Savinova TN, Matishov GG, Dahle S, Naes K 2003: Polycyclic aromatic hydrocarbons (PAHs) and organochlorines (OCs) in bottom sediments of the Guba Pechenga, Barents Sea, Russia. Sci Total Environ 306: $39-56$

Schlenk D, Di Giulio RT 2002: Biochemical responses as indicators of aquatic ecosystem health. In: Marshall Adams S (Ed.): Biological indicators of aquatic ecosystem stress. AFS, Bethesda, Maryland, pp. 14-17

Schlezinger JJ, Stegeman JJ 2001: Induction and supression of cytochrome P450 1A by 3,3',4,4',5pentachlorobiphenyl and its relationship to oxidative stress in the marine fish scup (Stenotomus chrysops). Aquat Toxicol 52: 101-115

Sen A, Semiz A 2007: Effects of metals and detergents on biotransformation and detoxification enzymes of leaping mullet (Liza saliens). Ecotox Environ Safe 68: 405-411

Sleiderink HM, Boon JP 1996: Temporal induction pattern of hepatic cytochrome P450 1A in thermally acclimated dab (Limanda limanda) treated with 3,3',4,4'- tetrachlorobiphenyl (CB77). Chemosphere 32: 2335-2344

Smith PK, Krohn RI, Hermanson GT, Mallia AK, Gartner FH, Provenzano MD, Fujimoto EK, Goeke NM, Olson BJ, Klenk DC 1985: Measurement of protein using bicinchoninic acid. Anal Biochem 150: 76-85

Stachel B, Ehrhorn U, Heemken OP, Lepom P, Reincke H, Sawal G, Theobald N 2003: Xenoestrogens in the River Elbe and its tributaries. Environ Pollut 124: 497-507

Stegeman JJ, Woodin Br, Singh H, Oleksiak MF, Celander M 1997: Cytochromes P450 (CYP) in tropical fishes: Catalytic activities, expression of multiple CYP proteins and high levels of microsomal P450 in liver of fishes from Bermuda. Comp Biochem Phys C 116: 61-75

Svobodová Z, Žlábek V, Randák T, Máchová J, Kolářová J, Hajšlová J, Suchan P 2003: Profiles of persistent organochlorine pollutants (POPs) in tissues of marketable common carp and in bottom sediments of selected ponds of South and West Bohemia. Acta Vet Brno 72: 295-309

Svobodová Z, Žlábek V, Randák T, Máchová J, Kolářová J, Hajšlová J, Suchan P, Dušek L, Jarkovský J 2004: Profiles of PCBs in tissues of marketable common carp and bottom sediments from selected ponds in South and West Bohemia. Acta Vet Brno 73: 133-142

Široká Z, Krijt J, Randák T, Svobodová Z, Pešková G, Fuksa J, Hajšlová J, Jarkovský J, Janská M 2005: Organic pollutant contamination of the River Elbe as assessed by biochemical markers. Acta Vet Brno 74: 293-303

Van Der Oost R, Beyer J, Vermeulen NPE 2003: Fish bioaccumulation and biomarkers in environmental risk assessment: a review. Environ Toxicol Phar 13: 57-149

White RD, Shea D, Stegeman JJ 1997: Metabolism of the aryl hydrocarbon receptor agonist 3,3',4,4`tetrachlorobiphenyl by the marine fish scup (Stenotomus chrysops) in vivo and in vitro. Drug Metab Dispos 25: 564-572

Whyte JJ, Jung RE, Schmitt CJ, Tillitt DE 2000: Ethoxyresorufin- $O$-deethylase (EROD) activity in fish as a biomarker of chemical exposure. Crit Rev Toxicol 30: 347-570

Willett KL, Wassenberg D, Lienesch L, Reichert W, Di Giulio RT 2001: In vivo and in vitro inhibition of CYP1Adependent activity in Fundulus heteroclitus by the polynuclear aromatic hydrocarbon fluoranthene. Toxicol Appl Pharm 177: 264-271

Wolkers J, Jorgensen EH, Nijmeijer SM, Witkamp RF 1996: Time-dependent induction of two distinct hepatic cytochrome P4501 A catalytic activities at low temperatures in Arctic charr (Salvelinus alpinus) after oral exposure to benzo $(a)$ pyrene. Aquat Toxicol 35: 127-138

Žlábek V, Svobodová Z, Randák T, Valentová O 2005: Mercury content in the muscle of fish from the Elbe River and its tributaries. Czech J Anim Sci 50: 528-534 